\title{
Screening of actinobacteria-producing amylolytic enzyme in sediment from Litopenaeus vannamei (Boone, 1931) ponds in Rembang District, Central Java, Indonesia
}

\author{
DIAH AYUNINGRUM ${ }^{1,2, \boldsymbol{v}}$, ANINDITIA SABDANINGSIH ${ }^{1,2}$, OKTAVIANTO EKO JATI $^{\mathbf{1}}$ \\ ${ }^{1}$ Department of Aquatic Resources, Faculty of Fisheries and Marine Sciences, Universitas Diponegoro. Jl. Prof. H. Soedarto, S.H, Tembalang, Semarang \\ 50275, Central Java, Indonesia. Tel.: +62-24-7474698, `email: diahayuningrum21@lecturer.undip.ac.id \\ ${ }^{2}$ Tropical Marine Biotechnology Laboraatory, Faculty of Fisheries and Marine Sciences, Universitas Diponegoro. Jl. Prof. H. Soedarto, S.H, Tembalang, \\ Semarang 50275, Central Java, Indonesia
}

Manuscript received: 2 February 2021. Revision accepted: 19 March 2021

\begin{abstract}
Ayuningrum D, Sabdaningsih A, Jati OE. 2021. Screening of actinobacteria-producing amylolytic enzyme in sediment from Litopenaeus vannamei (Boone, 1931) ponds in Rembang District, Central Java, Indonesia. Biodiversitas 22: 1819-1828. Coastal environments are dynamic places where various activities such as aquaculture take place. Waste from intensive aquaculture contains high amounts of organic material that negatively affect the pond system as well as the surrounding environment. Bioremediation using hydrolytic enzymes from microbes has been widely used as an alternative to remove organic waste because of its lower economic cost and more efficient. Microbes such as Gram-positive actinobacteria are widely known as enzyme producers. This research aimed to isolate actinobacteria from Litopenaeus vannamei pond sediment, to purify and characterize the actinobacteria based on morphological appearance, to conduct screening of amylolytic activity, and to identify the species of actinobacteria through 16S rDNA amplification as well as to construct their phylogenetic tree. Sampling was done in Rembang District, Central Java, Indonesia, with 5 sampling stations consist of 14 sampling points. Thirty-eight pure axenic cultures of actinobacteria were successfully isolated using two different media, namely IM6 and IM8. The IM8 medium promoted the most growth of 24 isolates rather than on the IM6 with only 14 isolates. Based on morphological appearance, most isolates belonged to Streptomyces-like actinomycete bacteria as many as 30 isolates and the rest 8 isolates belonged to mycelium-forming non-Streptomyces actinomycete bacteria. The screening results of amylolytic activity showed that all of the 38 actinobacteria formed halo zone with amylolytic index between 1.31-5.29. Top five highest amylolytic index was found in isolates SA4.1 (IM6), SD1.3 (IM8), SC3.3 (IM8), SC3.3 (IM6) and SC3.2 (IM8). The isolate SC3.3 (IM8) according to BLAST homology, showed a 98\% similarity with Streptomyces atacamensis C60. Further research is needed to investigate the potential of isolate SC3.3 (IM8) to reduce the BOD level in the aquatic system as a bioremediator candidate.
\end{abstract}

Keywords: Bioremediation, hydrolytic enzyme, organic waste, mycelium-forming non-Streptomyces actinomycete, Streptomyces-like actinomycete

\section{INTRODUCTION}

Cultivated fishery products, mainly shrimp, have contributed as the highest export income for Indonesia as many as $37 \%$ of the total of all fishery products (Ministry of Marine Affairs and Fisheries Republic of Indonesia 2018). According to the Ministry of Marine Affairs and Fisheries (2019), Indonesia can extend its aquaculture ponds to cover 2,964,331.24 ha and have sustainable potential shrimp productivity of 886.520 tons/year with Java Island at the center of productivity $(28.52 \%)$. The potential is based on the further development of traditional ponds to become intensive ponds. If intensive cultivation technology is applied, the potential increases as marginal sandy and peatlands can be turned into ponds. The most promising commodity in shrimp aquaculture is vanname shrimp (Litopenaeus vannamei) with productivity reaches 6-10 tons/ha/year (Awanis et al. 2017). Rembang District is one of the centers of intensive vaname shrimp cultivation in Central Java with 27,570 ha (27\%) of its total area with total production of $5,585,173 \mathrm{~kg}$ which equal to $\mathrm{Rp}$ $349,014,494.00$ (USD 24,682 at the time of writing) in
2015 (RPIJM 2018-2022).

Despite the advantages of intensive vaname shrimp cultivation technology, it increases the amount of waste produced as feed residue, feces, shrimp carapaces, and dead plankton that settle at the bottom of the pond. Leftover feed and the product of shrimp metabolism settle as sediment containing organic material such as $\mathrm{N}, \mathrm{P}_{2} \mathrm{O}_{5}$, $\mathrm{K}_{2} \mathrm{O}_{3}$ and C-Organic (Suwoyo et al. 2015). High amount of waste leads to water quality reduction, which increases the risk of various diseases among the shrimp (Avnimelech and Ritvo 2003). Therefore, waste management is a major issue associated with vaname shrimp cultivation in intensive ponds. This may reduce the water quality in the cultivation system and in nearby rivers and seas. Without proper management and monitoring of waste disposal, intensive cultivation of vaname shrimp is likely to harm the environment. In high-intensity ponds with stocking densities of 750-1,250 shrimp $/ \mathrm{m}^{3}$, sediment can reach 18.221.9 tons/0.1 ha per shrimp production cycle (Suwoyo et al. 2015). According to Preston et al. (2001), sludge formed during the cultivation process can reach 35-60 tons/ha per shrimp production cycle. The decomposition of feed 
residue produces toxins and causes disease in vanname shrimp (Patang 2016), thus reducing the productivity of the pond as well as the profit.

Management and monitoring of water quality in shrimp ponds and bioremediation strategies are important to overcome the excess organic matter in pond sediments. Bioremediation technologies for removing these contaminants provide a safe and economical alternative to commonly used physical-chemical treatment (Karigar and Rao 2011). Bacterial activity is the major process involved in the hydrolysis of organic pollutants. Hydrolytic bacteria are bacteria capable of secreting hydrolytic enzymes such as amylase, protease, lipase, DNAse, and xylanase to catabolize major biomass components polysaccharides, proteins, and fats (Ethica et al. 2018a). Bioprospecting bacteria to produce hydrolytic enzymes for bioremediation purposes has been done by some researchers. Ethica et al. (2018b) isolated bacteria from the liquid biomedical waste with hydrolytic capability as protease producers (26 colonies), amylase producers (14 colonies), cellulose producers (13 colonies) and lipase producers (10 colonies). Some members from phylum of actinobacteria from the bacteria domain also being reported of its potency to produce hydrolytic enzyme from marine environments and shrimp culture pond sediments such as lipase, amylase, chitinase, pectinase, and ligninase enzymes which showing bioremediation potential in Penaeus monodon shrimp culture by significantly reducing Biochemical Oxygen Demand (BOD) level (Babu et al. 2018). The high level of BOD indicates the high organic matters in the water systems, it has an impact to Dissolved Oxygen (DO) which is the most important of water quality parameter for shrimp (Bui et al. 2012). Therefore, this study attempted to isolate and purify the actinobacteria from vanname shrimp pond sediment, to purify and characterize their morphological appearance, and investigate the potential of actinobacteria isolates in producing amylolytic enzymes as the initial approach in bioremediation of vanname shrimp pond.

\section{MATERIALS AND METHODS}

\section{Sediment sampling}

Samples of sediment were collected from L. vannamei ponds in June 2020 in Rembang District, Central Java, Indonesia, from five sampling stations with 14 sampling points (Figure 1). The $20 \mathrm{~cm}$ top layer of sediment was collected with a sterile spade (box-corer), placed in sterile zip-lock bags, and stored in an ice-cooled cool box. The samples were stored in the fridge at $4^{\circ} \mathrm{C}$ in the Laboratory of Tropical Marine Biotechnology (TMB), Diponegoro University, Semarang, Central Java before the isolation process.

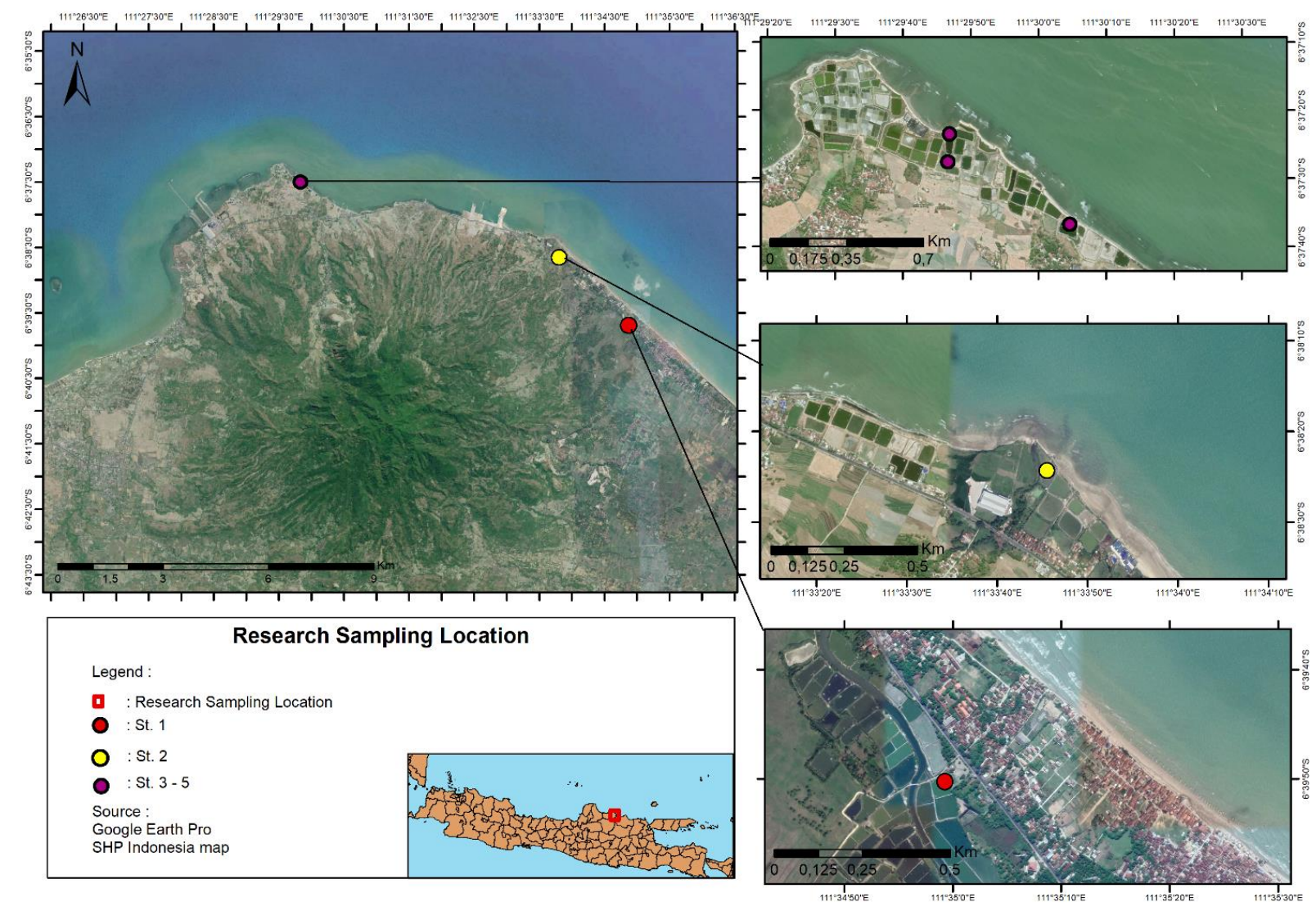

Figure 1. Sediment sampling sites from L. vannamei ponds in Rembang District, Central Java, Indonesia. Red dot: Site 1 comprising 4 sampling points. Yellow dot: Site 2 comprising 4 sampling points. Dark red dot: Sites 3, 4, and 5 comprising 3, 1, and 2 sampling points respectively 
Table 1. Description of sediment type from each sampling point

\begin{tabular}{cllll}
\hline Site & Sample ID & Depth $(\mathbf{m})$ & Location (in relation to the pond) & Sediment type \\
\hline 1 & SA.1 & $0-0.2$ & Outlet of pond & Fine muddy sand \\
& SA.2 & $0-0.2$ & Outlet of pond close to mangrove vegetation & Clay and mud \\
& SA.3 & $0-0.2$ & Inside the pond after harvest & Fine muddy sand \\
& SA. 4 & $0-0.2$ & Inside the pond after harvest & Fine muddy sand \\
2 & SB.1 & $0-0.2$ & Outlet of pond & Sand \\
& SB. 2 & $0-0.2$ & Outlet of pond & Clay and sand with small stones \\
& SB.3 & $0-0.2$ & Inside long-term not being used pond & Sand and mud \\
& SB. 4 & $0-0.2$ & Outlet of pond & Mud and small stones \\
3 & SC.1 & $0-0.2$ & Inside the pond & Clay and sand \\
& SC. 2 & $0-0.2$ & Inlet of the pond & Clay and sand \\
& SC. 3 & $0-0.2$ & Outlet of the pond & Clay and sand \\
4 & SD. 1 & $0-0.2$ & Outlet of pond & Clay and mud \\
5 & SE.1 & $0-0.2$ & Outlet of pond & Mud and sand \\
& TGSE. 1 & $0-0.2$ & Inside of the pond & Clay and mud \\
\hline
\end{tabular}

Descriptions and IDs of processed sediment samples from the five different locations are presented in Table 1. Sediment from each sampling site differed in type. Site 1 was located approximately $500 \mathrm{~m}$ from the shoreline, characterized by the predominantly muddy and sandy sediment. Site 2 was located close to the shoreline approximately $10 \mathrm{~m}$ and its sediment was predominantly made up of sand and small stones such as dead coral fragments from the coast. Sites 3 and 4 were also located close to the shoreline and consisted predominantly of similar elements of clay. Site 5 predominantly consisted of mud elements.

\section{Isolation media}

We used isolation media IM6 and IM8 with compositions according to Bredholt et al. (2008), except for a small modification to IM6 because asparagine is not readily available in Indonesia. They consisted of the following. IM6: glycerol (0.5 g), starch (0.5 g), sodium propionate $(0.5 \mathrm{~g}), \quad \mathrm{KNO}_{3}(0.1 \mathrm{~g})$, casein $(0.3 \mathrm{~g})$, $\mathrm{K}_{2} \mathrm{HPO}_{4}(0.5 \mathrm{~g}), \mathrm{FeSO}_{4}(1 \mathrm{mg})$, agar $(20 \mathrm{~g})$, vitamin $\mathrm{B}$ solution (Vitamin B complex IPI) $(1 \mathrm{~mL})$, natural seawater $(0.5 \mathrm{~L})$ and distilled water $(0.5 \mathrm{~L})$. IM8: malt extract $(1 \mathrm{~g})$, glycerol $(1 \mathrm{~g})$, glucose $(1 \mathrm{~g})$, peptone $(1 \mathrm{~g})$, yeast extract $(1$ $\mathrm{g})$, agar $(20 \mathrm{~g})$, natural sea water $(0.5 \mathrm{~L})$, and distilled water $(0.5 \mathrm{~L})$. The $\mathrm{pH}$ of the isolation media was adjusted to $\mathrm{pH}$ 8.2. Vitamin B complex solution consisted of the following: Vitamin B1 (2 mg), Vitamin B2 (2 mg), Vitamin B6 (2 mg), Calcium pantothenate $(10 \mathrm{mg})$, Nicotinamide $(20 \mathrm{mg})$ and sterile distilled water $(10 \mathrm{~mL})$. All isolation media were amended with nystatin (70 $\mu \mathrm{g} / \mathrm{mL})$ as antifungal and nalidixic acid $(30 \mu \mathrm{g} / \mathrm{mL})$ as antiGram negative bacteria.

\section{Isolation and purification of actinobacteria}

The samples were processed on the same day or the day after sampling. Isolation was done with a dilution method according to Bredholt et al. (2008) with modifications. Sediments were diluted with sterile seawater down to $1: 10$ (v/v) and vigorously shaken with a shaker at $120 \mathrm{rpm}$ for $10 \mathrm{~min}$. After settling for $5 \mathrm{~min}$, the upper part of sediment suspensions as many as $50 \mu \mathrm{L}$ were plated onto different selective agar media and incubated at room temperature $\left(25 \pm 2{ }^{\circ} \mathrm{C}\right)$ for $2-6$ weeks. The actinobacteria colonies were identified by the powdery appearance or velvetic, rough mycelium and slow-growing (Babu et al. 2018). All colonies with different colony's margin, elevation, surface, shape, aerial hyphae, substrate hyphae and size were separated into new agar medium (IM6 or IM8) according to the agar for isolation. The purification method was using streak plate method (Madigan et al. 2013).

\section{Morphological characterization of actinobacteria}

Initial morphological characterization was based on appearance including the colony's margin, elevation, surface, shape, aerial hyphae, substrate hyphae and size (Benson 2002; Asnani et al. 2015). All actinobacteria isolates were documented from the top and bottom view to observe the features of aerial and mycelium hyphae. Further morphological characterization for the actinobacteria isolates was according to the Bergey's Manual of Systematic Bacteriology (Goodfellow et al. 2012).

\section{Screening of amylase activity}

Screening of amylase activity was using starch casein nitrat media. The composition according to Asnani et al. (2015) was as follows. Starch $(10 \mathrm{~g})$, casein $(1 \mathrm{~g}), \mathrm{KNO}_{3}(1$ g), $\mathrm{K}_{2} \mathrm{HPO}_{4}(0.5 \mathrm{~g}), \mathrm{MgSO}_{4.7} \mathrm{H}_{2} \mathrm{O}(0.5 \mathrm{~g}), \mathrm{NaCl}(0.5 \mathrm{~g})$, $\mathrm{FeSO}_{4.7} \mathrm{H}_{2} \mathrm{O}(0.01 \mathrm{~g})$, and agar $(15 \mathrm{~g})$. The actinobacteria isolates were inoculated as a dot onto the starch medium and were incubated at room temperature $\left(25 \pm 2^{\circ} \mathrm{C}\right)$ for 7 days. This was done in duplicate to avoid bias in the screening result. The Lugol's iodine solution was used as an indicator of the presence in amylase activity by forming a halo zone surrounding the colony (Babu et al. 2018; Luang-In et al. 2019). Otherwise, the colony which is not produced amylase, after being tested with iodine the 
surrounding medium will turn out dark blue. Thus, the isolates with a clear hydrolysis zone were considered amylase producers, and the halo zone diameter and the colony diameter were measured and recorded in $\mathrm{mm}$ (Pranay et al. 2019). The ratio between halo zone diameter calculated specific zones or amylolytic index compared to colony diameter (Islam et al. 2016).

\section{DNA extraction and amplification of 16S rDNA}

The extraction of genomic DNA was using Quick-DNA Miniprep Plus Kit Catalog Nos. D4068 \& D4069 from Zymo Research following the protocol for biological fluids $\&$ cells. The purity of the DNA was measured by Nanodrop (Thermo Scientific Nanodrop 2000 Uv-Vis Spectrophotometer) for the result of A260/280. The amplification of 16S rDNA was performed using universal primer PA 5'-AGA GTT TGA TCC TGG CTC AG-3' and PH 5'-AAG GAG GTG ATC CAG CCG CA-3'. PCR reaction with a total of $25 \mu \mathrm{L}$ was consist of $1 \mu \mathrm{L}$ DNA template, each primer of $1 \mu \mathrm{L}$, $\mathrm{ddH}_{2} \mathrm{O}$ of $9.5 \mu \mathrm{L}$ and mix PCR $\quad$ MyTaq $^{\text {TM }}$ Red Mix-Bioline) of $12.5 \mathrm{~mL}$. Amplification reaction was conducted in a Thermal Cycler (BIO-RAD) T100 using optimization of consist of initial denaturation at $95{ }^{\circ} \mathrm{C}$ for $10 \mathrm{~min} ; 34$ cycles of denaturation at $95^{\circ} \mathrm{C}$ for $45 \mathrm{~s}$, annealing at $50^{\circ} \mathrm{C}$ for $60 \mathrm{~s}$, extension at $72^{\circ} \mathrm{C}$ for $90 \mathrm{~s}$; final extension at $72^{\circ} \mathrm{C}$ for $5 \mathrm{~min}$ (Ayuningrum et al. 2019). The examination of PCR products was using gel electrophoresis with agarose $1 \%$, and the result was visualized by using UVIDoc HD5 (UVITEC Cambridge, UK). The amplicon with desired size of $1500 \mathrm{bp}$ was sent to $1^{\text {st }}$ base, Malaysia for further sequencing analysis.

\section{BLAST homology and phylogenetic tree}

After the sequencing analysis was done, the resulting sequences were processed to create BLAST homology
(Pearson 2013). The consensus result of the actinobacteria isolate was submitted to GenBank (www.ddbj.nig.ac.jp). The sequencing results were analyzed and the phylogenetic tree was constructed with MEGA X software (Kumar et al. 2018) and features neighbor-joining (Saitou and Nei 1978).

\section{RESULT AND DISCUSSION}

\section{Isolation and purification of actinobacteria}

In this study, we use two media, IM6 and IM8, resulting in 38 actinobacteria isolates according to morphological observation with detailed isolation information on each sampling site performed in Figure 2. The results of isolating actinobacteria using IM6 and IM8 contained different isolate quantities. The first site (Site A) only showed two points where actinobacteria were successfully isolated. Sites B and C had one point in each site, where actinobacteria did not be detected. Both sites D and E where all of the sampling points successfully isolated the actinobacteria. There were 4 sampling points in site A, B and C, those were SA.1, SA.3, SB.3 and SC.1, where the actinobacteria isolate were not detected but only bacterial colonies. This might because of many factors such as culture media, culture conditions, pre-treatment of the sample, isolation technique, incubation time, etc (Davis et al. 2005). Culture media play significant role in isolation of microbes because the composition of each carbon source, nitrogen source, inhibiting agent, growth factor and gelling agent determine the cultural environment in which the microbes suitable to grow or not (Bonnet et al. 2020). Most of the sediment microbes are not easily isolated using single kind of medium, due to its low frequency of which bacterial cells in it to form visible colonies when isolated with standard media (Guan et al. 2020; Davis et al. 2005).

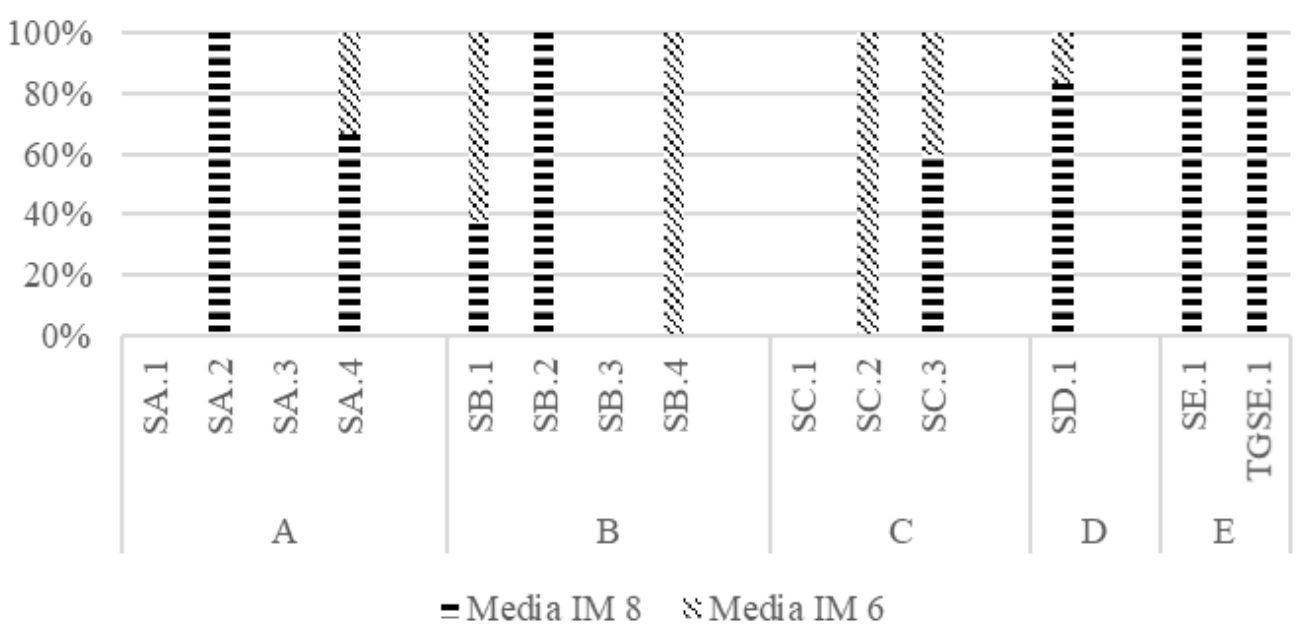

Figure 2. The comparison of both media in isolation of actinobacteria from L. vannamei pond sediment. Site A, B, C, D and E showed different percentages of isolated actinobacteria according to the different media. There were 4 sampling points (SA.1, SA.3, SB.3, and SC.1) where actinobacteria isolate not detected. Meanwhile, 4 sampling points (SA.2, SB.2, SE.1, and TGSE.1) where actinobacteria successfully isolated using IM 8 medium, yet only 2 sampling points (SB.4 and SC.2) isolated using IM6 media. The other sampling point varies in percentage, 40\%, 60\% and 80\% actinobacteria isolated from sampling points SB.1, SC.2, and SD.1 using medium IM8, while the rest $60 \%, 40 \%$ and $20 \%$ using IM6 medium respectively 
The isolation results were strongly affected by the composition and availability of the medium. Even though from the same sample, the colonies grown on the different media varied in their morphology and viable count of the colony. Research from Lilja (2013) reported that the use of different media (VPB/VPA, SCN, IM6, IM7, IM8) resulting different number of isolated actinobacteria from marine samples with most of it isolated from VPB medium. Another research from Bredholt et al. (2008) using four different media (IM5, IM6, IM7, and IM8) to isolate actinobacteria from Trondheim fjord sediment resulting in different number of viable counts of bacteria and actinobacteria on each medium. There were some sampling points where the actinobacteria nor bacteria were not detected as well. In our study, most of the actinobacteria were growing on the IM8 medium as many as 24 isolates rather than on the IM6 (14 isolates) medium as shown in Figure 3.

In this study, actinobacteria isolates seem to prefer growing on the IM8 medium over the IM6 medium because of the composition of both media. The source of carbon and protein is different for both media. The IM6 has starch as source of carbon and glycerol, while casein as protein source. Meanwhile, the IM8 medium has carbon from malt, glycerol, and glucose also protein sources from peptone and yeast. From this composition, protein sources in IM8 more plentiful than in IM6, so that it affects the number of successfully isolated actinobacteria.

\section{Morphological characterization of actinobacteria}

The hyphae or mycelium of the actinobacteria are divided into two types, namely substrate and aerial. All actinobacteria colonies were morphologically characterized according to margin, elevation, shape, aerial hyphae, substrate hyphae, and size of the colony. Substrate or vegetative hyphae develop from outgrowth of germinating spores and grow on the surface of culture media with function to absorb nutrients. Substrate hyphae produce pigment and give color to the substrate as well as aerial hyphae. On the other hand, aerial hyphae grow up into the air when substrate hyphae enter a certain stage and produce spores (Hamedi and Poorinmohammad 2017). Besides microscopy and polyphasic data, both hyphae are essential for the identification of actinobacteria. The morphological characterizations of actinobacteria are presented in Table 2.

Further, according to Bredholt et al. (2008) the actinomycete-like morphology isolates which formed powdery colonies with well-developed aerial hyphae fragmented into spore chains were tentatively termed as Streptomyces-like actinomycete bacteria (SA). Meanwhile, the other isolates formed orange to red-pigmented colonies with solid colony texture, non-fragmenting substrate mycelium that lacked aerial hyphae and often turned purple, brown or black upon sporulation, and was tentatively termed as MNSA (mycelium-forming nonStreptomycete actinomycete bacteria). The other morphological characters of genus Streptomyces according to Bergey's Manual of Systematic Bacteriology
(Goodfellow et al. 2012) are the colonies discrete and lichenoid, leathery, or butyrous. Most of the colonies initially show a smooth surface, but then develop a weft of aerial mycelium that may appear floccose, granular, powdery, or velvety. The Streptomyces colony can also produce pigments with a wide variety of colors responsible for the color of substrate and aerial mycelia. According to it, we classified as many as 30 isolates were belonged to Streptomyces-like actinomycete bacteria (SA), while the rest 8 isolates were belonged to MNSA. The color of aerial hyphae on SA is mostly gray and full of spores.

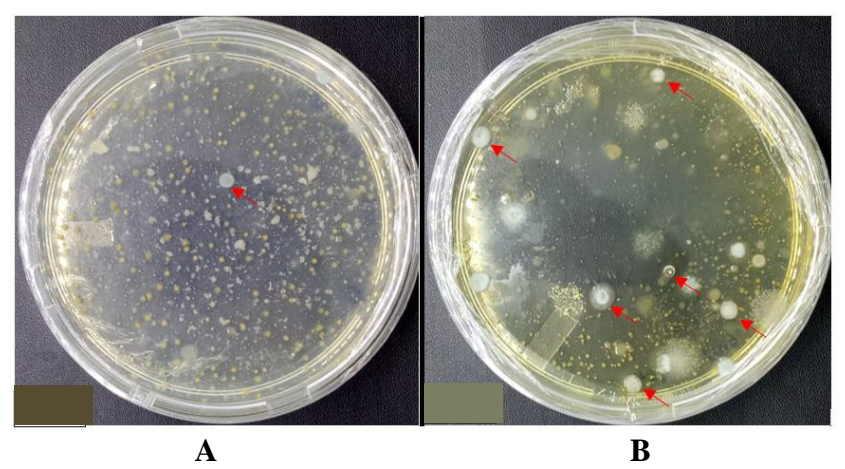

Figure 3. Both plates contain the same inoculum from sediment in sampling point SA.2 on the same day $(3 \mathrm{w})$ yet observed the difference in quantities of colonies grown on the media and all the different morphology of colonies. A. Sample was isolated using IM6 medium, which showed only one actinobacterium isolate with aerial hyphae (red arrow) and other yellow pin-point actinobacteria. B. Sample was isolated using IM8 medium which showed more actinobacteria isolates (red arrow) than A.
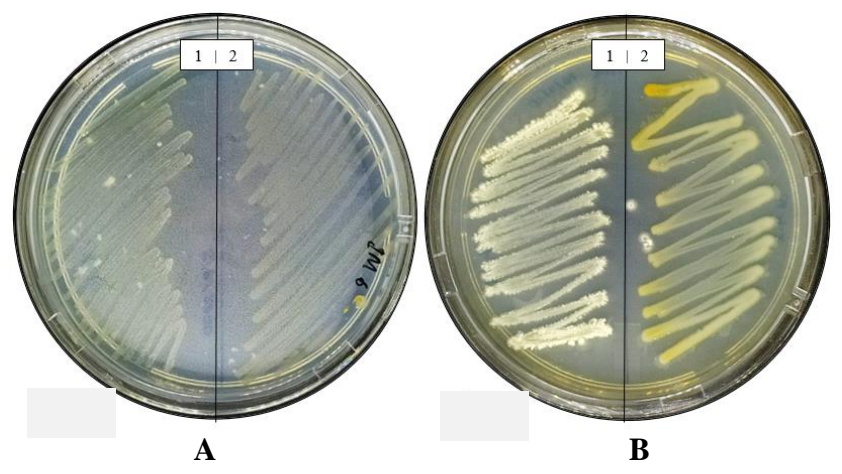

Figure 4. The difference in colony morphology between Streptomyces-like actinomycete bacteria (SA) and myceliumforming non-Streptomycete actinomycete bacteria (MNSA). Both A-B were from the same isolates, SA 4.1 (A1 \& B1) and SA 4.2 (A2 \& B2) with different culture ages. A. Taken at the 3 days old culture, meanwhile, B. Taken at 20 days old culture. The SA 4.1 (A1\&B1) observed to be having the aerial mycelia with powdery spore and white-colored, therefore it belonged to SA. On the other hand, SA 4.2 did not perform the aerial hyphae nor the spore, but only the white mycelium, therefore it belonged to MNSA. 
Table 2. The morphological characterizations of actinobacteria colonies

\begin{tabular}{|c|c|c|c|c|c|c|c|c|}
\hline Isolate code & Media & Margin & Elevation & Surface & Shape & Aerial hyphae & Substrate hyphae & Size (mm) \\
\hline SA 2.1 & IM 8 & Irregular & Umbonate & Powdery & Irregular & Gray & Cream & 11 \\
\hline SA 2.2 & IM 8 & Irregular & Umbonate & Powdery & Irregular & Gray & White & 9 \\
\hline SA 2.4 & IM 8 & Irregular & Convex & Powdery & Irregular & Gray & White & 2 \\
\hline SA 2.5 & IM 8 & Irregular & Convex & Powdery & Irregular & Gray & White & 15.7 \\
\hline SA 2.6 & IM 8 & Irregular & Convex & Powdery & Irregular & Gray & Yellow & 9.7 \\
\hline SA 2.7 & IM 8 & Irregular & Convex & Powdery & Irregular & Gray & Creamy white & 10 \\
\hline SA 4.1 & IM 6 & Irregular & Convex & Powdery & Round & Gray & Greenish-yellow & 1 \\
\hline SA 4.1 & IM 8 & Irregular & Umbonate & Powdery & $\begin{array}{l}\text { Round with } \\
\text { radiating } \\
\text { margin }\end{array}$ & White & Yellow & 3 \\
\hline SA 4.2 & IM 8 & Lobate & Flat & - & Round & - & Yellow & 1 \\
\hline SB 1.1 & IM 8 & Irregular & Umbonate & Powdery & Irregular & Gray & Greenish-yellow & 5 \\
\hline SB 1.2 & IM 6 & Irregular & Umbonate & Powdery & Round & Gray & White & 3 \\
\hline SB 1.2 & IM 8 & Irregular & Umbonate & Powdery & Irregular & Light gray & Yellow & 8 \\
\hline SB 1.3 & IM 6 & Irregular & Flat & - & Irregular & - & Yellow & 1 \\
\hline SB 1.4 & IM 6 & Irregular & Convex & Powdery & Irregular & Gray & Gray & 1.5 \\
\hline SB 1.5 & IM 6 & Irregular & Umbonate & Powdery & Irregular & Gray & White & 4 \\
\hline SB 1.6 & IM 6 & Irregular & Convex & Powdery & Irregular & Gray & Gray & 2.5 \\
\hline SB 1.6 & IM 8 & Irregular & umbonate & Powdery & round & Gray & Gray & 3 \\
\hline SB 2.4 & IM 8 & Wavy & Umbonate & Powdery & Irregular & Gray & Creamish white & 3 \\
\hline SB 2.6 & IM 8 & Wavy & Umbonate & Rough & Irregular & Gray & Cream & 7.83 \\
\hline SB 4.1 & IM 6 & Irregular & Umbonate & Powdery & Irregular & Greenish gray & Gray & 2 \\
\hline SB 4.2 & IM 6 & Irregular & Hilly & - & Irregular & - & Yellow & 2 \\
\hline SC 2.1 & IM 6 & Irregular & Umbonate & Powdery & round & Light gray & Yellow & 2 \\
\hline SC 2.2 & IM 6 & Lobate & Raised & - & Irregular & - & - & 2 \\
\hline SC 2.3 & IM 6 & Irregular & Umbonate & Powdery & Round & White & Orange & 5 \\
\hline SC 3.1 & IM 6 & Irregular & Umbonate & Powdery & Irregular & Gray & Yellow & 3 \\
\hline SC 3.1 & IM 8 & Wavy & Convex & Powdery & Round & Gray & White & 2 \\
\hline SC 3.2 & IM 8 & Wavy & Umbonate & Rough & Round & Gray & White & 2 \\
\hline SC 3.3 & IM 6 & Irregular & Umbonate & Powdery & Irregular & White & White & 2 \\
\hline SC 3.3 & IM 8 & Irregular & Umbonate & Powdery & Round & White & Yellow & 2.5 \\
\hline SD 1.1 & IM 8 & Wavy & Convex & Powdery & Irregular & Greenish white & White & 3.3 \\
\hline SD 1.2 & IM 8 & Irregular & Umbonate & Powdery & Irregular & White & Cream & 1 \\
\hline SD 1.3 & IM 8 & Irregular & Umbonate & Powdery & Irregular & White & Yellow & 2 \\
\hline SD 1.4 & IM 8 & Lobate & Umbonate & Powdery & Round & Greenish gray & Yellow & 2 \\
\hline SD 1.5 & IM 6 & Irregular & Umbonate & Powdery & Irregular & Light gray & Yellow & 2 \\
\hline SD 1.5 & IM 8 & Irregular & Umbonate & Powdery & Irregular & Gray & Greenish yellow & 3 \\
\hline SE 1.1 & IM 8 & Irregular & Convex & - & Irregular & - & White & 1 \\
\hline SE 1.3 & IM 8 & Smooth & Convex & - & Round & - & Gray & 1 \\
\hline TGSE 4 & IM 8 & Irregular & Convex & Powdery & Irregular & White & Yellow & 3 \\
\hline
\end{tabular}

Note: - : Not present

SA can easily be observed by the presence of spiral chains belonging to multiple spores, whereas MNSA's spores are differently organized, such as in a single spore or a bispore, which are mostly present in Saccharomonospora and Microbispora (Hamedi and Poorinmohammad 2017). SA also has a long chain spore that contains more than 100 spores. Morphological differences between SA and MNSA are presented in Figure 4. Some MNSA may belong to other genera in the family of Actinomycetaceae or belong to another family in the phylum of Actinobacteria. The colonies from family Actinomycetaceae may be filamentous giving a more or less mycelial appearance, but aerial mycelium is usually not formed. Most species produce non-filamentous predominantly white or gray colonies, while some species may develop pigmented colonies (deep red, reddish, brown, pink, pinkish, or yellowish) (Goodfellow et al. 2012). Some actinobacteria of the family Micromonosporaceae don't produce aerial hyphae and instead only produce substrate hyphae (Hamedi and Poorinmohammad 2017). Other taxa such as Intrasporangium, Kineosporia, Mycobacteria, Rhodococci, and Tsukamurella spumae also do not have aerial hyphae (O'Leary 1989; Rosenberg et al. 2014).

\section{Screening of amylolytic activity}

Amylolytic activity is the ability of microorganisms to degrade carbohydrate sources, such as starch, becoming smaller molecules such as glucose, dextrose, and maltose. The results of screening amylolytic activity are presented in Table 3. All actinobacteria isolates showed positive activity in degrading starch, indicated by the formation of a halo zone. 
Table 3. The amylolytic screening results

\begin{tabular}{ccccc}
\hline $\begin{array}{c}\text { Isolate } \\
\text { code }\end{array}$ & $\begin{array}{c}\text { Isolation } \\
\text { media }\end{array}$ & $\begin{array}{c}\text { Average of } \\
\text { amylolytic } \\
\text { activity (mm) }\end{array}$ & $\begin{array}{c}\text { Average } \\
\text { of colony } \\
\text { diameter } \\
\text { (mm) }\end{array}$ & $\begin{array}{c}\text { Amylolytic } \\
\text { index }\end{array}$ \\
\hline SA 2.1 & IM 8 & 43.72 & 23.17 & 1.89 \\
SA 2.2 & IM 8 & 20.15 & 15.25 & 1.32 \\
SA 2.4 & IM 8 & 19.62 & 10.11 & 1.94 \\
SA 2.5 & IM 8 & 40.38 & 22.92 & 1.76 \\
SA 2.6 & IM 8 & 30.51 & 13.06 & 2.34 \\
SA 2.7 & IM 8 & 31.03 & 16.12 & 1.93 \\
SA 4.1 & IM 6 & 39.37 & 7.44 & 5.29 \\
SA 4.1 & IM 8 & 40.28 & 28.84 & 1.40 \\
SA 4.2 & IM 8 & 36.70 & 21.62 & 1.70 \\
SB 1.1 & IM 8 & 43.38 & 27.28 & 1.59 \\
SB 1.2 & IM 6 & 30.16 & 19.92 & 1.51 \\
SB 1.2 & IM 8 & 36.84 & 22.97 & 1.60 \\
SB 1.3 & IM 6 & 56.31 & 40.08 & 1.41 \\
SB 1.4 & IM 6 & 26.20 & 13.84 & 1.89 \\
SB 1.5 & IM 6 & 21.82 & 12.79 & 1.71 \\
SB 1.6 & IM 6 & 38.93 & 20.79 & 1.87 \\
SB 1.6 & IM 8 & 31.68 & 18.61 & 1.70 \\
SB 2.4 & IM 8 & 30.05 & 22.45 & 1.34 \\
SB 2.6 & IM 8 & 8.79 & 5.29 & 1.66 \\
SB 4.1 & IM 6 & 22.00 & 13.63 & 1.61 \\
SB 4.2 & IM 6 & 18.75 & 14.33 & 1.31 \\
SC 2.1 & IM 6 & 21.74 & 6.98 & 3.11 \\
SC 2.2 & IM 6 & 6.20 & 4.75 & 1.31 \\
SC 2.3 & IM 6 & 13.42 & 4.84 & 2.77 \\
SC 3.1 & IM 6 & 41.86 & 20.65 & 2.03 \\
SC 3.1 & IM 8 & 29.06 & 21.13 & 1.38 \\
SC 3.2 & IM 8 & 31.22 & 8.62 & 3.62 \\
SC 3.3 & IM 6 & 34.15 & 9.38 & 3.64 \\
SC 3.3 & IM 8 & $\mathbf{4 3 . 1 4}$ & $\mathbf{1 1 . 4 5}$ & $\mathbf{3 . 7 7}$ \\
SD 1.1 & IM 8 & 19.36 & 6.79 & 2.85 \\
SD 1.2 & IM 8 & 24.51 & 7.58 & 3.23 \\
SD 1.3 & IM 8 & 33.98 & 8.99 & 3.78 \\
SD 1.4 & IM 8 & 27.94 & 9.50 & 2.94 \\
SD 1.5 & IM 6 & 23.60 & 9.70 & 2.43 \\
SD 1.5 & IM 8 & 18.06 & 12.92 & 1.40 \\
SE 1.1 & IM 8 & 28.57 & 15.55 & 1.84 \\
SE 1.3 & IM 8 & 14.82 & 5.87 & 2.52 \\
\hline & IM 8 & 28.62 & 10.56 & 2.71 \\
\hline
\end{tabular}

Bacteria that hydrolyzed starch are known to produce exoenzyme amylase which hydrolyzes starch into short polysaccharides known as dextrins and cleave them into diand monosaccharides (de Souza and Magalhães 2010). Transparent zones resulting from starch degradation caused by amylase enzymes produced by actinobacteria isolates are presented in Figure 5.

Degradation processes of organic matter are the result of the combined effort of billions of individual microorganisms. All microbial cells have highly diverse metabolic potentials and requirements and are continuously involved in synergetic or competitive interactions that determine the outcome of their activities. Natural organic matter deposited on the sea floor comprises a complex mixture of high-molecular-weight compounds that cannot be taken up directly by the cells. Therefore, extracellular hydrolysis is required to produce smaller, monomeric organic molecules such as sugars and amino acids (Arndt et al. 2013).

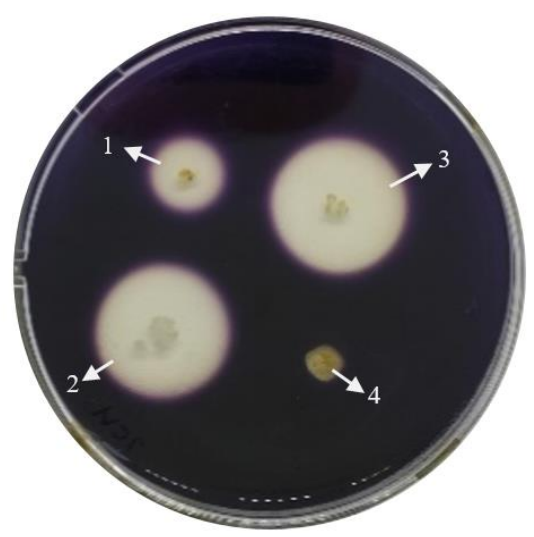

Figure 5. Screening of amylolytic activity from actinobacteria isolates SC 2.2 IM6 (1), SC 2.1 IM6 (2), SC 2.3 IM6 (3), and SC 2.4-bacteria IM6 (4). All of the isolates showed different halo zone diameters which isolate no. $1(\mathrm{~d}=6 \mathrm{~mm})$, no. $2(\mathrm{~d}=15 \mathrm{~mm})$, no. $3(\mathrm{~d}=16 \mathrm{~mm})$, and no. 4 no amylolytic activity (no halo zone).
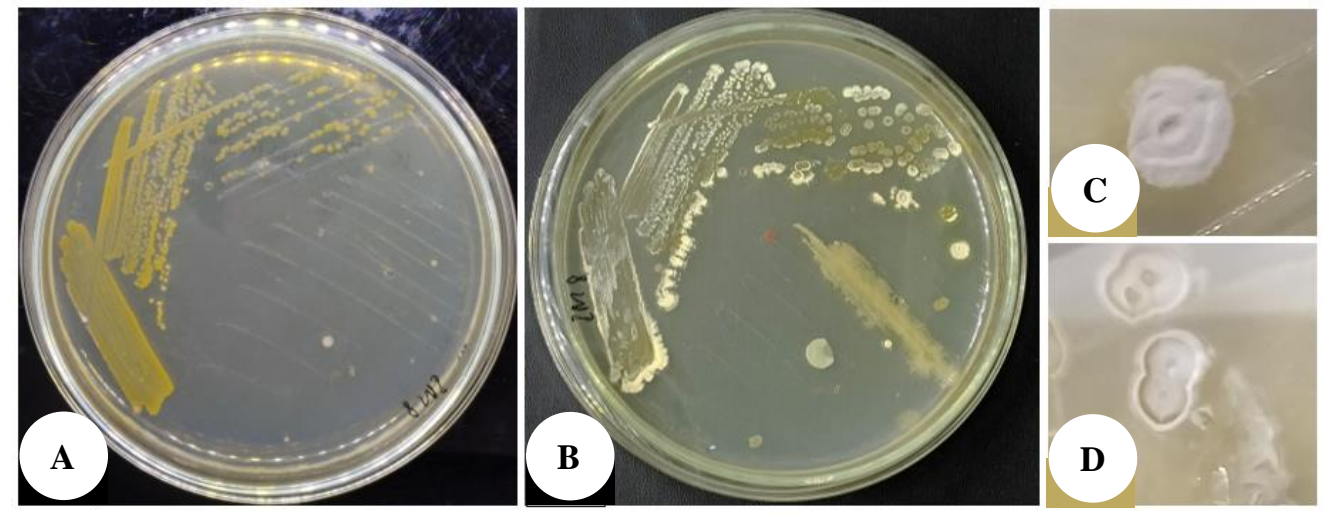

Figure 6. The colony's morphology of isolate SC 3.3 (IM 8) at different stages. A> Taken when the isolate at 4 days old. The colony was colored yellow from the substrate hyphae, with slightly white color on the top of some colonies which indicates the presence of aerial mycelium. B. Taken when the isolate at 46 days old, showed the white aerial mycelium with powdery spore. C-D. The structure of the spore was performed at 30 days old. 


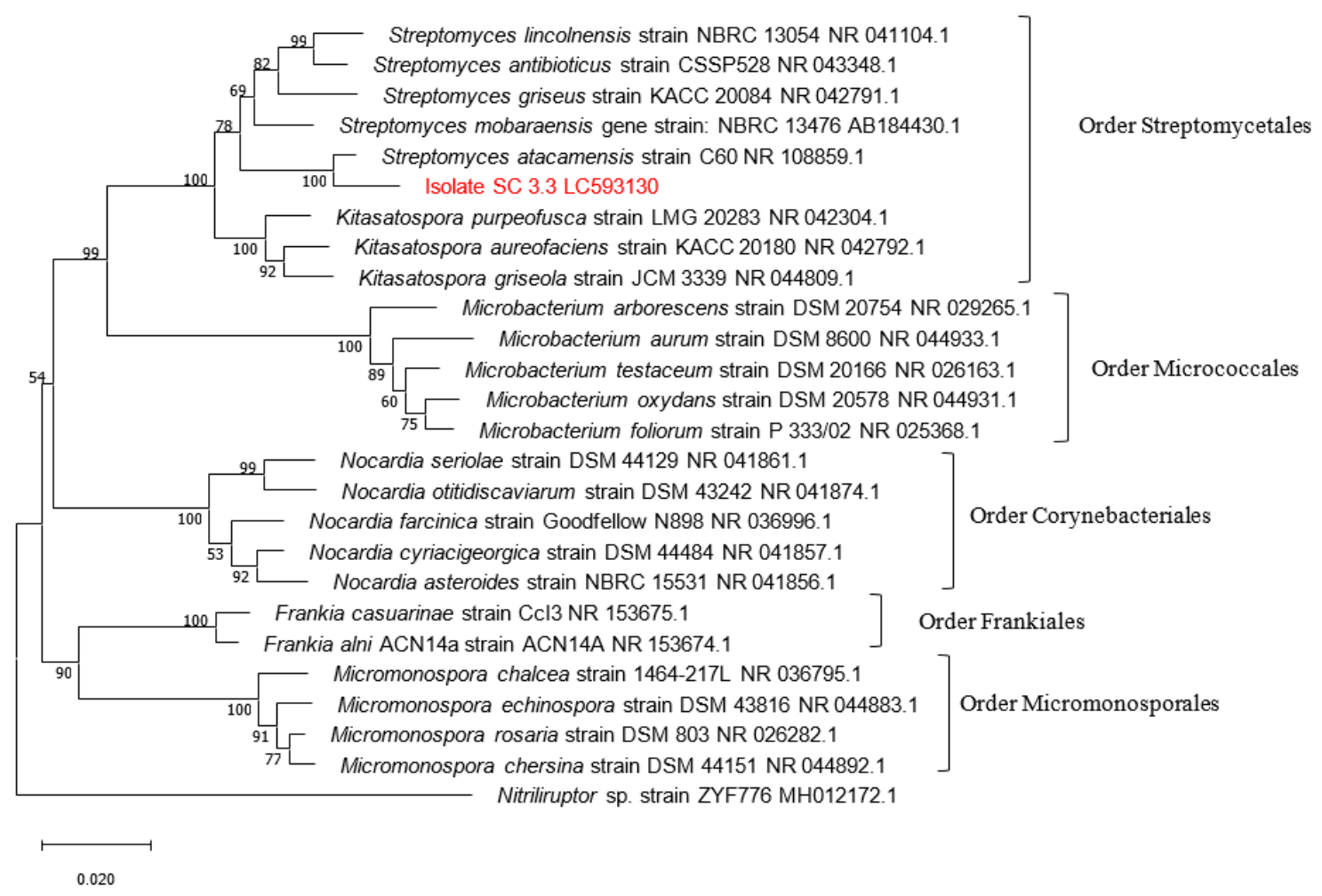

Figure 7. A neighbor-joining phylogenetic tree based on 16S rDNA region, with 1000 bootstrap replications. The number of each node presents bootstrap values from Neighbor-Joining (NJ). The potential isolate as amylolytic producer was indicated by red letters.

The five highest amylolytic index were presence from the isolate SA 4.1 (IM6), SD 1.3 (IM8), SC 3.3 (IM8), SC 3.3 (IM6) and SC 3.2 (IM8). In this study, we identified isolate SC 3.3 (IM8) for further molecular identification. Before that, the morphological appearance of the isolate was shown in Figure 6. According to morphological colony observation, the isolate SC 3.3 (IM 8) was closely similar to the morphological characteristic of genus Streptomyces in Bergey's Manual of Systematic Bacteriology (Goodfellow et al. 2012).

Much research has been reported on the production of amylase enzymes from genus Streptomyces, most of them isolated from soil or marine environment. Streptomyces clavifer isolated from soil samples in Saudi Arabia produce high level of $\alpha$-amylase which can be used on industrial scale (Yassien and Asfour 2012). Another research from Kafilzadeh and Dehdari (2015) also found the potential of gnus Streptomyces isolated from mangrove sediment in amylase enzyme production. There has been reported research that Streptomyces from wide variety of environments like cold places (Antarctica) or associated with invertebrates were potential for the production of amylase enzyme (Cotarlet et al. 2011; Khrisnakumar et al. 2015). Research from Babu et al. (2018) reported that some Streptomyces species such as Streptomyces coelicoflavus, Streptomyces diastaticus, Streptomyces parvus and Streptomyces champavatii were able to produce hydroliytic enzymes (protease, lipase, amylase, chitinase, pectinase, and ligninase) which further have potential as bioremediator agent in $P$. monodon culture system by the reduction of BOD level in the cultivation system.

\section{Amplification of partial 16S rDNA}

The molecular identification of actinobacteria isolates was similar to other bacterial isolates because it belongs to domain bacteria. This Actinobacteria phylum consists of six classes: Rubrobacteria, Thermoleophilia, Coriobacteriia, Acidimicrobiia, Nitriliruptoria, and Actinobacteria(Goodfellow et al. 2012). The amplification of $16 \mathrm{~S}$ rDNA from actinobacteria isolates SC 3.3 (IM8) displayed a 1500 bp gene length. The results from BLAST homology showed that isolate SC 3.3 (IM8) had a similarity of $98.3 \%$ with Streptomyces atacamensis C60. Isolate SC 3.3 (IM8) may therefore be proposed as a new species since different order with similarity values of 98.7$99 \%$ have been proposed as such in the past (Stackebrandt and Ebers 2006). However, further research is needed into SC 3.3's morphological, biochemical, and molecular characterizations.

\section{The phylogenetic tree}

Streptomyces atacamensis SC3.3 belongs to the order Streptomycetales in phylum Actinobacteria. This phylum consists of 6 classes and 13 orders, where one of the class taxa also has the same name as the phylum, namely Class Actinobacteria (Ludwig et al. 2015). Figure 7 demonstrates the position of isolate SC 3.3 in the phylogenetic tree was in the same clade with genera Streptomyces and 
Kitasatospora, which both belonging to the order Streptomycetales. The closest clade was from genus Microbacterium order Micrococcales, followed by the order Frankiales and Micromonosporales. The furthest clade was order Corynebacteriales and the outgroup was genus Nitriliruptor from class Nitriliuptoria, different class from Actinobacteria.

Beneficial compounds such as antibiotics, enzymes, inhibitors, and other pharmacologically active compounds are well known to be produced by members of the genus Streptomyces (Bérdy 2005; Khamna et al. 2009; Zhao et al. 2011). Some actinobacteria can produce and secrete extracellular amylases for them to carry out extracellular digestion, these are species of Streptomyces erumpens and Thermobifida fusca (El-Sersy et al. 2010; Zhang et al. 2011). The future demand for amylases is predicted to reach $25 \%$ in the global enzyme market and microorganisms such as Streptomyces spp. will play an important role in biotechnological applications (Mukhtar et al. 2017). Therefore, the actinobacteria are potential candidates for hydrolytic enzyme producers with wide variety of biotechnological applications such as bioremediator agents.

In conclusion, a total of 38 pure axenic cultures of actinomycete was successfully isolated from L. vannamei pond sediment, which more than a half (30 isolates) belonged to Streptomyces-like Actinomycete. All of these actinomycete isolates were capable of producing amylase enzymes with wide variety of amylolytic indexes. One of the top five highest amylolytic index was found in isolates SC 3.3 which according to BLAST homology, showed a 98\% similarity with Streptomyces atacamensis C60. Further research is needed to investigate the potential of isolate SC3.3 in producing the other hydrolytic enzymes and reduce the BOD level in the aquatic system as a bioremediator candidate.

\section{ACKNOWLEDGEMENTS}

This study was funded by LPPM Diponegoro University, Semarang, Indonesia through the Riset Penerapan dan Pengembangan (RPP) scheme with contract No. 233-83/ UN7.6.1/PP/2020. The authors are grateful for the assistance that Diva Triza Novitasari and Farha Tsabita provided in our research in the laboratory.

\section{REFERENCES}

Arndt S, Jørgensen BB, LaRowe DE, Middelburg JJ, Pancost RD, Regnier P. 2013. Quantifying the degradation of organic matter in marine sediments: A review and synthesis. Earth-Sci Rev 123 (2013): 53-86. DOI: 10.1016/j.earscirev.2013.02.008

Asnani A, Ryandini D, Suwandri. 2015. Karakterisasi dan identifikasi spesies Aktinomisetes K-3e. Prosiding Seminar Nasional "Pengembangan Sumber Daya Perdesaan dan Kearifan Lokal Berkelanjutan V", Purwokerto, 19-20 November 2015. [Indonesian]

Avnimelech Y, Ritvo G. 2003. Shrimp and fish pond soils: Processes and management. Aquaculture 220: 549-567. DOI: 10.1016/S00448486(02)00641-5.

Awanis AA, Prayitno SB, Herawati VE. 2017. Kajian kesesuaian lahan tambak udang vaname dengan menggunakan sistem informasi geografis di Desa Wonorejo, Kecamatan Kaliwungu, Kendal, Jawa Tengah. Buletin Oseanografi Marina 6 (2): 102-109. [Indonesian]

Ayuningrum D, Kristiana R, Nisa AA, Radjasa SK, Muchlissin SI, Radjasa OK, Sabdono A, Trianto A. 2019. Bacteria associated with Tunicate, Polycarpa aurata, from Lease Sea, Maluku, Indonesia exhibiting anti-multidrug resistant bacteria. Biodiversitas 20 (4): 956964. DOI: $10.13057 /$ biodiv/d200404

Babu DT, Archana K, Kachiprath B, Solomon S, Jayanath G, Singh ISB, Philip R. 2018. Marine actinomycetes as bioremediators in Penaeus monodon rearing system. Fish Shellfish Immunol 75: 231-242. DOI: 10.1016/j.fsi.2018.01.037.

Benson HJ. 2002. Microbiological Applications: A Laboratory Manual in General Microbiology. 8th ed. The McGraw-Hill Company, New York.

Bérdy J. 2005. Bioactive microbial metabolites. J Antibiot 58: 1-26. DOI: 10.1038/ja.2005.1.

Bonnet M, Lagier JS, Raoult D, Khelaifia S. 2020. Bacterial culture through selective and non-selective conditions: the evolution of culture media in clinical microbiology. New Microbe New Infect 34: 100622. DOI: 10.1016/j.nmni.2019.100622.

Bredholt H, Fjærvik E, Johnsen G, Zotchev SB. 2008. Actinomycetes from sediments in the Trondheim Fjord, Norway: diversity and biological activity. Mar Drugs 6 (1): 12-24. DOI: 10.3390/md6010012

Bui TD, Luong-Van J, Austin CM. 2012. Impact of shrimp farm effluent on water quality in coastal areas of the world heritage-;isted Ha Long Bay. Am J Environ Sci 8 (2): 104-116. DOI: 10.3844/ajessp.2012.104.116

Cotarlet M, Negoita TG, Bahrim GE, Stougaard PE. 2011. Partial characterization of cold active amylases and proteases of Streptomyces sp. from Antarctica. Braz J Microbiol 42 (3): 868-877. DOI: $10.1590 / \mathrm{S} 1517-83822011000300005$.

Davis KER, Joseph SJ, Janssen PH. 2005. Effects of growth medium, inoculum size, and incubation time on culturability and isolation of soil bacteria. Appl Environ Microbiol 71 (2): 826-834. DOI: 10.1128/AEM.71.2.826-834.

de Souza PM, Magalhães PO. 2010. Application of Microbial $\alpha$-Amylase in Industry - A Review. Braz J Microbiol 41: 850-861. DOI: 10.1590/S1517-83822010000400004.

El-Sersy NA, Abd-Elnaby H, Abou-Elela GM, Ibrahim HAH, El-Toukhy NMK, et al. 2010. Optimization, economization and characterization of cellulose produced by marine Streptomyces ruber. Afr J Biotechnol 9 (38): 6355-6364.

Ethica SN, Saptaningtyas R, Muchlissin SI, Sabdono A. 2018a. The development method of bioremediation of hospital biomedical waste using hydrolytic bacteria. Health Technol 8: 239-254. DOI: 10.1007/s12553-018-0232-8.

Ethica SN, Muchlissin SI, Saptaningtyas R, Sabdono A. 2018b. Protease producers predominate cultivable hydrolytic bacteria isolated from liquid biomedical waste. Asian J Chem 30 (9): 2035-2038. DOI: 10.14233/ajchem.2018.21400

Goodfellow M, Kampfer P, Busse H, Trujillo ME, Suzuki K, Ludwig W, Whitman WB. 2012. Bergey's Manual of Systematic Bacteriology $2^{\text {nd }}$ edition volume 5 The Actinobacteria, Part A and B. Springer, New York. DOI: 10.1007/978-0-387-68233-4.

Guan T, Lin Y, Ou M, Chen K. 2020. Isolation and diversity of sediment bacteria in the hypersaline aiding lake, China. PLoS ONE 15 (7): e0236006. DOI: 10.1371/journal.pone.0236006

Hamedi J, Poorinmohammad N. 2017. The Cellular Structure of Actinobacteria. In: Wink J, Mohammadipanah F, Hamedi J (Eds) Biology and Biotechnology of Actinobacteria. Springer, Switzerland.

Islam MR, Mondol OK, Rahman MS, Billah MM, Rahman MS, Zohora US. 2016. Screening of $\alpha$-amylase producing bacteria from tannery wastes of Hazaribag, Bangladesh. Jahangirnagar Univ J Biol Sci 5 (2): 1-10. DOI: 10.3329/jujbs.v5i2.32511.

Kafilzadeh F, Dehdari F. 2015. Amylase activity of aquatic actinomycetes isolated from the sediments of mangrove forests in south of Iran. Egypt J Aquat Res 41: 197-201. DOI: 10.1016/j.ejar.2015.04.003.

Karigar CS, Rao SS. 2011. Role of microbial enzymes in the bioremediation of pollutants: A Review. Enzyme Res 805187. DOI: 10.4061/2011/805187.

Khamna S, Yokota A, Lumyong S. 2009. Actinomycetes isolated from medicinal plant rhizosphere soils: diversity and screening of antifungal compounds, indole-3-acetic acid and siderophore production. World J Microbiol Biotechnol 25: 649-655. DOI: $10.1007 /$ s11274-008-9933-x. 
Khrisnakumar S, Bai VDM, Premkumar J. 2015. Production of alpha amylase by salt-tolerant Streptomyces sp. SBU3 isolated from marine sponge. Indian J Geo-Mar Sci 44 (4):583-588.

Kumar S, Stecher G, Li M, Knyaz C, Tamura K. 2018. MEGA X: Molecular evolutionary genetics analysis across computing platforms. Mol Biol Evol 35 (6): 1547-1549. DOI: 10.1093/molbev/msy096

Lilja T. 2013. Isolating microorganisms from marine and marineassociated samples - A targeted search for novel natural antibiotics. Independent project in Biology. Swedish University of Agricultural Science, Upsala. [Swedish]

Luang-In V, Yotchaisarn M, Saengha W, Udomwong P, Deeseenthum S, Maneewan K. 2019. Isolation and identification of amylase-producing bacteria from soil in Nasinuan Community Forest, Maha Sarakham, Thailand. Biomed Pharmacol J 12 (3): 1061-1068. DOI: $10.13005 / \mathrm{bpj} / 1735$

Ludwig W, Euzeby J, Busse H, Trujillo ME, Kampfer P, Whitman WB. 2015. Road map of the phylum Actinobacteria. In: Bergey's Manual of Systematic of Archaea and Bacteria. John Wiley \& Sons, Inc. DOI: 10.1002/9781118960608.bm00029

Madigan MT, Martinko JM, Stahl DA, Clark DP. 2013. Brock Biology of Microorganisms $13^{\text {th }}$ edition. Pearson Education, Inc., San Fransisco, CA.

Ministry of Marine Affairs and Fisheries Republic of Indonesia. 2018 Kinerja Ekspor Produk Perikanan Indonesia Tahun 2018. https://kkp.go.id/djpdspkp/artikel/7947-kinerja-ekspor-produkperikanan-indonesia-tahun-2018

Ministry of Marine Affairs and Fisheries Republic of Indonesia. 2019. Pengembangan Komoditas Unggulan Strategis Perikanan Budidaya, Dan Tata Kelola Perizinan Untuk Memacu Investasi. Ministry of Marine Affairs and Fisheries Republic of Indonesia, Jakarta. [Indonesian]

Mukhtar S, Zaheer A, Aiysha D, Malik KA, Mehnaz S. 2017. Actinomycetes: A source of industrially important enzymes. J Proteomics Bioinform 10: 12. DOI: 10.4172/0974-276X.1000456

O'Leary WM. 1989. Practical Handbook of Microbiology. CRC Press, Boca Raton.

Patang. 2016. Pengembangan Udang Windu Melalui Penerapan Pembantutan, Probiotik dan Pengendalian Lingkungan. Orasi ilmiah pengukuhan guru besar disampaikan pada sidang terbuka luar biasa senat Universitas Negeri Makassar, 27 Desember 2016 , Makassar. [Indonesian]

Pemerintah Kabupaten Rembang. 2018. Review Rencana Program Investasi Jangka Menengah (RPIJM) Bidang Cipta Karya Kabupaten Rembang Tahun 2018 - 2022. Pemerintah Kabupaten Rembang, Rembang. [Indonesian]

Pranay K, Padmadeo SR, Jha V, Prasad B. 2019. Screening and identification of amylase-producing strains of Bacillus. J Appl Biol Biotechnol 7 (4): 57-62. DOI: 10.7324/JABB.2019.70409

Preston NP, Jackson CJ, Thompson P, Austin M, Burford MA, Rothlisberg P. 2001. Prawn farm effluent: composition, origin and treatment. Fishing Res Dev Corporation Final Rep 95: 162.

Pearson WR. 2013. An Introduction to sequence similarity ("homology") searching. Curr Protoc Bioinformatics 42 (1): 3-1. DOI: 10.1002/0471250953.bi0301s42.

Rosenberg E, DeLong EF, Lory S, Stackebrandt E, Thompson F. 2014. The Prokaryotes: Actinobacteria. Springer, Berlin.

Saitou N, Nei M. 1987. The neighbor-joining method: A new method for reconstructing phylogenetic trees. Mol Biol Evol 4: 406-425. DOI: 10.1093/oxfordjournals.molbev.a040454.

Stackebrandt E, Ebers J. 2006. Taxonomic parameters revisited: tarnished gold standards. Microbiol Today 33 (4): 152-155.

Suwoyo HS, Tahe S, Fahrur M. 2015. Karakterisasi limbah sedimen tambak udang vaname (Litopenaeus vannamei) super intensif dengan kepadatan berbeda. Prossiding Forum Inovasi Teknologi Akuakultur 2015: 1015-1026. [Indonesian]

Yassien MAM, Asfour HZ. 2012. Improved production, purification and some properties of $\alpha$-amylase from Streptomyces clavifer. Afr J Biotechnol 11 (80): 14603-14611. DOI: 10.5897/AJB12.1790.

Zhang F, Chen JJ, Ren WZ, Nie GX, Ming H. 2011. Cloning, expression and characterization of an alkaline thermostable GH9 endoglucanase from Thermobifida halotolerans YIM 90462 T. Biores Technol 102: 10143-10146. DOI: 10.1016/j.biortech.2011.08.019.

Zhao K, Penttinen P, Guan T, Xiao J, Chen Q, Xu J, Lindström K, Zhang L, Zhang X, Strobel GA. 2011. The diversity and anti-microbial activity of endophytic actinomycetes isolated from medicinal plants in Panxi Plateau, China. Curr Microbiol 62: 182-190. DOI: 10.1007/s00284-010-9685-3. 